\title{
REPPELENCY TO SPIDER MITE MEDIATED BY THE GENE MI AND BY THE SYNERGISM BETWEEN HIGH FOLIAR CONTENTS OF ACYLSUGAR AND ZINGIBERENE IN TOMATO
}

\author{
REPELÊNCA AO ÁCARO-RAJADO MEDIADA PELO GENE Mi E PELO \\ SINERGISMO ENTRE ALTOS TEORES FOLIARES DE ACILAÇÚCARES E DE \\ ZINGIBERENO EM TOMATEIRO
}

\section{Celso Mattes de OLIVEIRA ${ }^{1}$; Wilson Roberto MALUF ${ }^{2}$; Thiago Matos ANDRADE $^{3}$; Aline MARCHESE; ${ }^{4}$ André LASMAR ${ }^{2}$; Gisele Cristina de Oliveira MENINO5; Alcinei Místico AZEVEDO ${ }^{6}$}

Pesquisador, Doutor, Agro Carregal Pesquisa e Proteção de Plantas, Rio Verde, GO, Brasil. celsodoliveira@ yahoo.com.br. 2. Professor, Doutor, Departamento de Agricultura, UFLA, Lavras, MG, Brasil; 3. Professor, Doutor, Nucleo de Graduação de Agronomia, UFS, Campus do Sertão, Nossa Senhora da Glória, SE, Brasil. 4. Professora, Doutora, Universidade Federal do Paraná ,UFPR, Setor de Palotina, Paraná, PR. 5. Professora, Doutora, Instituto Federal Goiano - IFgoiano, Rio Verde, GO, Brasil. 6. Professor, Doutor, Instituto Ciencias Agrarias, ICA, Montes Claros,MG, Brasil.

\begin{abstract}
Tomato fruits (Solanum Lycopersicum) are intended for human consumption in its in natura or industrially processed form. However, the expansion of its cultivation area has favored the emergence of pests, such as spider mite (Tetranychus urticae), which significantly affects the production. The objective of this study was to quantify and evaluate the repellency of tomato lines to spider mite in function of the gene $M i$ and of the individual and synergistic effects of acylsugar and zingiberelene allelochemicals. The experiment consisted of a complete randomized design with four replications. For the bioassay, four fully expanded leaflets with similar size were removed from the upper third of the plants at pre-flowering phenological stage. The bioassay was carried out in a cold chamber, at $16 \pm 1^{\circ} \mathrm{C}$, and $64 \pm 4 \% \mathrm{RH}$. The gene $M i$ was not effective in conferring repellency to spider mite. On the other hand, zingiberene and acylsugar were efficient and equivalent regarding repellency to spider mite. When combined in tomato lines, zingiberene and acylsugar had synergistic effect, which increased repellency to spider mite.
\end{abstract}

KEYWORDS: Tetranychus urticae. Solanum lycopersicum. Breeding

\section{INTRODUCTION}

Tomato (Solanum lycopersicum) is grown worldwide. In Brazil, it is cultivated in about 71,000 hectares, with approximately yield of 4.5 million tons (FAO, 2013). The culture is considered as of high risk due to several health problems, especially the high degree of pest infestation (SUINAGA et al., 2003).

Among tomato arthropod-pests, mites of the Tetranychus genus stand out for causing drought in leaves, followed by defoliation, reduction in size and number of fruits, and early ripening (FLECHTMANN; BAKER, 1970). The Tetranychus genus comprises several species; however, only three are important for tomato culture: the spider mite (T. urticae Koch.), and the red spider mites $T$. ludeni Zacher and $T$. evansi Baker Pritchard. Of these three species, spider mite is the most relevant in Brazil (FLECHTMANN, 1989).

Mites in general, including the Tetranychus genus, have high capacity of population increase, reaching 20-25 generations per year (LARA, 1991). Consequently, the effective control of this pest is necessary in order to keep the population below the economic injury level. Currently, chemical control is the most common pest control; however, it is not so effective due to the ability of mites to develop resistance against several groups of acaricides. This resistance probably occurs due to the use of not recommended doses and to the high frequency of spraying (Lara, 1991), which also causes problems to the environment and to human health. Therefore, the development of resistant cultivars is of great importance, since it has permanent effect on the pest population, and does not directly affect their natural enemies, which consequently avoids the use of acaricides (LARA, 1991).

In Brazil, tomato breeding programs aimed at resistance to pests are based on the selection of genotypes with high foliar contents of allelochemicals associated with resistance. Among these allelochemicals, acylsugar and zingiberene stand out for conferring resistance to Tetranychus urticae, Tuta absoluta, and Bemisia argentifolii 
(MALUF et al., 2001; GONÇALVES et al., 2006; PEREIRA et al., 2008; RESENDE et al., 2006; RESENDE et al., 2008; SILVA et al., 2009; MACIEL et al., 2011; BLEEKERA et al., 2012; OLIVEIRA et al., 2012; NEIVA et al., 2013;). Thus, the development of lines with high zingiberene or acylsugar content, and which are resistant to arthropods-pests has increased (SILVA et al., 2009; MALUF et al., 2010; OLIVEIRA et al., 2012).

Although high zingiberene and acylsugar contents are important in the obtainment of plants resistant to pests, little is known in relation to the effects on spider mite and to the synergistic effect of these two allelochemicals. According to Marchese (2013), the incorporation of two or more allelochemicals may increase the spectrum of resistance to pests, making it more difficult to be broken. The effect of the gene $M i$ on mite is another key information not found in the literature. The gene $M i$ confers resistance to nematodes of the Meloidogyne spp. genus, which was introduced in tomato plants cultivated from $S$. peruvianum species (SMITH, 1944).

Thus, the objective of this study was to evaluate the repellency of tomato lines to spider mite in function of the presence of the gene $M i$, and the individual and synergistic effects of acylsugar and zingibereleno allelochemicals.

\section{MATERIAL AND METHODS}

Two tomato lines with high foliar acylsugar content (TOM-687, TOM-688) and two tomato lines with high foliar zingiberene content (ZGB-703, ZGB-704) were obtained from crosses between cultivated tomatoes ( $S$. lycopersicum) with the wild accessions Solanum pennellii 'LA-716' and $S$. habrochaites var. hirsutum 'PI-127826'. 'TOM-687' and 'TOM-688' were obtained from the interspecific cross $S$. lycopersicum x $S$. pennellii 'LA-716', followed by three backcrosses with $S$. lycopersicum, and selected based on their high acylsugar content (PEREIRA et al., 2008; GONÇALVES NETO et al., 2010), according to the methodology proposed by Rezende et al. (2002). 'ZGB-703' and 'ZGB704 'were obtained from the interspecific crosses $S$. lycopersicum x $S$. habrochaites var. hirsutum 'PI127826', followed by two backcrosses with $S$. lycopersicum, and selected based on their high zingiberene sesquiterpene content (GONÇALVES et al., 2006).

Lines with high acylsugar and zingiberene contents were also obtained by crossing the lines
ZGB-703/ZGB-704 and TOM-688/TOM-689 (the latter also presents high acylsugar content). Their segregating populations from F2 to F7 generations were selected for high contents of both allelochemicals. Two F7 populations of these crosses were considered fixed for high contents of both acylsugar and zingiberene, and were designated as BPX-413E-02-161-207-31-6-20-325 and BPX-413E-02-161-207-31-6-6-367. Individual plants of these F7 populations were selected for good agronomic traits (especially size and fruit quality) and cloned via stem cuttings. Clones (T8 to T34, Table 1) were used in repellency tests to spider mite Tetranychus urticae. Three lines susceptible to T. urticae and with low contents of both acylsugar and zingiberene were also used (RESENDE et al., 2006; MARCHESE, 2013), being two of them ('Santa Clara' and TOM-584) susceptible to nematodes (not carrying the $M i$ allele), and one resistant to nematodes (TOM-684) (carrying the $M i$ allele in homozygosity) (MARCHESE, 2013).

The populations BPX-413E-02-161-207-316-20-325 and BPX-413E-02-161-207-31-6-6-367 were sown in polystyrene trays and cultivated in plastic greenhouse, in the municipality of Ijaci, MG (lat. $21^{\circ} 14^{\prime} 16^{\prime \prime} \mathrm{S}$, long. $45^{\circ} 08^{\prime} 00^{\prime \prime} \mathrm{W}$, at $918 \mathrm{~m}$ ), together with the lines TOM 584, TOM-684, TOM687, TOM-688, ZGB-703 and ZGB-704. Forty plants of each BPX-413E populations, and 20 plants of each control lines were evaluated individually, according to the colorimetric methods described by de Freitas (1999) for zingiberene, and by Resende et al. (2002) for acylsugar, in order to confirm the highest contents of the two allelochemicals simultaneously.

Eight plants of the BPX-413E-02-161-20731-6-20-325 population and 17 of the BPX-413E02-161-207-31-6-6-367 population (named from T8 to T34 in Table 1 ) were selected for testing, totaling 25 plants. Plants T8 to T34 (Table 1) were cloned by stem cutting for repellence tests to spider mite (Tetranychus urticae). Repellency to spider mite was measured using the bioassay proposed by Weston and Snyder (1990).

The experiment consisted of a complete randomized design with four replications. Four expanded leaflets of similar size were removed from the upper third of the plants at pre-flowering phenological stage. Mites were collected from tomato and green bean plants, obtained by means of the rearing and maintenance of the Acarology Laboratory of the Regional EPAMIG of South of Minas Gerais, located in Lavras, Brazil. 
Table 1. Description of zingiberene content (ZGB), acylsugar conten (AA) and presence of the gene $M i$ in 34 tomato genotypes. UFLA: Lavras, 2014.

\begin{tabular}{|c|c|c|c|c|}
\hline Id. & Treatments & $\begin{array}{l}\text { AA } \\
\text { content }\end{array}$ & ZGB content & $\begin{array}{l}\text { Presence of the } M I \\
\text { allele }\end{array}$ \\
\hline $\mathrm{T} 1$ & Santa Clara & - & - & - \\
\hline $\mathrm{T} 2$ & TOM 584 & - & - & - \\
\hline $\mathrm{T} 3$ & TOM 684 & - & - & + \\
\hline $\mathrm{T} 4$ & TOM 687 & + & - & - \\
\hline T5 & TOM 688 & + & - & - \\
\hline T6 & ZGB 703 & - & + & - \\
\hline $\mathrm{T} 7$ & ZGB 704 & - & + & - \\
\hline $\mathrm{T} 8$ & BPX-413E-02-161-207-31-6-20-325-107 & + & + & - \\
\hline T9 & BPX-413E-02-161-207-31-6-20-325-116 & + & + & - \\
\hline T10 & ВPX-413E-02-161-207-31-6-20-325-125 & + & + & - \\
\hline T11 & BPX-413E-02-161-207-31-6-20-325-128 & + & + & - \\
\hline T12 & ВPX-413E-02-161-207-31-6-20-325-129 & + & + & - \\
\hline $\mathrm{T} 13$ & BPX-413E-02-161-207-31-6-6-367-102 & + & + & - \\
\hline $\mathrm{T} 14$ & BPX-413E-02-161-207-31-6-6-367-107 & + & + & - \\
\hline $\mathrm{T} 15$ & BPX-413E-02-161-207-31-6-6-367-111 & + & + & - \\
\hline T16 & BPX-413E-02-161-207-31-6-6-367-112 & + & + & - \\
\hline T17 & ВРX-413E-02-161-207-31-6-6-367-113 & + & + & - \\
\hline T18 & BPX-413E-02-161-207-31-6-6-367-114 & + & + & - \\
\hline T19 & ВРX-413Е-02-161-207-31-6-6-367-115 & + & + & - \\
\hline T20 & ВРX-413E-02-161-207-31-6-6-367-126 & + & + & - \\
\hline $\mathrm{T} 22$ & BPX-413E-02-161-207-31-6-6-367-128 & + & + & - \\
\hline $\mathrm{T} 23$ & BPX-413E-02-161-207-31-6-6-367-129 & + & + & - \\
\hline $\mathrm{T} 24$ & BPX-413E-02-161-207-31-6-6-367-132 & + & + & - \\
\hline T25 & ВPX-413E-02-161-207-31-6-6-367-133 & + & + & - \\
\hline $\mathrm{T} 26$ & BPX-413E-02-161-207-31-6-6-367-134 & + & + & - \\
\hline $\mathrm{T} 27$ & BPX-413E-02-161-207-31-6-6-367-135 & + & + & - \\
\hline T28 & ВPX-413E-02-161-207-31-6-6-367-137 & + & + & - \\
\hline $\mathrm{T} 29$ & BPX-413E-02-161-207-31-6-20-325-104 & + & + & - \\
\hline $\mathrm{T} 30$ & BPX-413E-02-161-207-31-6-20-325-110 & + & + & - \\
\hline $\mathrm{T} 31$ & BPX-413E-02-161-207-31-6-20-325-123 & + & + & - \\
\hline T32 & ВРX-413E-02-161-207-31-6-20-325-124 & + & + & - \\
\hline $\mathrm{T} 33$ & BPX-413E-02-161-207-31-6-6-367-101 & + & + & - \\
\hline $\mathrm{T} 34$ & BPX-413E-02-161-207-31-6-6-367-104 & + & + & - \\
\hline
\end{tabular}

- Low content; + high content

The bioassay was carried out in a cold chamber, at $16 \pm 1{ }^{\circ} \mathrm{C}$ and $64 \pm 4 \% \mathrm{RH}$. Leaflets of each genotype were fixed with a metallic thumbtack ( $9 \mathrm{~mm}$ diameter) in the central region of the abaxial leaf surface, in a sulphite paper sheet, on a styrofoam tray, on which they were randomly distributed. Five female mites were taken from the rearing and transferred to the center of each thumbtack with the aid of a thin brush. The mean distance traveled by mites (in $\mathrm{mm}$ ) on the surface of each leaflet were measured from the center of the thumbtack after 20, 40 and 60 minutes. Smaller distances travelled by mites were considered indicative of higher levels of repellency. The distance traveled by the mites which remained on the thumbtack was considered zero.

Data were analyzed using the SAS statistical package (SAS Institute, 1990), and treatment means were compared by the Duncan test. Non-orthogonal contrasts were used for contrasts of interest among treatment groups (Table 2) and tested by the $t$ test, at $5 \%$ nominal significance.

Table 2. Description of contrasts of interest used for contrasts between genotypes and/or groups of genotypes with different zingiberene contents (ZGB) and acylsugar contents (AA). UFLA: Lavras, 2014.

\begin{tabular}{lll}
\hline Id. & Estimated contrasts & Description \\
\hline C1 & T1-T2 & Controls susceptible to nematodes vs low AA and ZGB contents \\
C2 & T1- T3 & $\begin{array}{l}\text { Control susceptible to nematodes (low AA and low ZGB) vs control } \\
\text { resistant to nematodes (low AA and low ZGB), carrying the gene } M i\end{array}$ \\
C3 & T2-T3 & $\begin{array}{l}\text { Control susceptible to nematodes (low AA and low ZGB) vs control } \\
\text { resistant to nematodes (low AA and low ZGB), carrying the gene } M i\end{array}$ \\
C4 & T4-T5 & Between lines with high AA content (both susceptible to nematodes) \\
C5 & T6-T7 & Between lines with high ZGB content (both susceptible to nematodes) \\
\hline
\end{tabular}




\begin{tabular}{|c|c|c|}
\hline C6 & $(\mathrm{T} 1+\mathrm{T} 2) / 2-(\mathrm{T} 4+\mathrm{T} 5) / 2$ & Effect of high AA content (alone) \\
\hline $\mathrm{C} 7$ & $(\mathrm{~T} 1+\mathrm{T} 2) / 2-(\mathrm{T} 6+\mathrm{T} 7) / 2$ & Effect of high ZGB content (alone) \\
\hline $\mathrm{C} 8$ & $(\mathrm{~T} 1+\mathrm{T} 2) / 2-(\mathrm{T} 8+\mathrm{T} 9+\ldots .+\mathrm{T} 34) / 27$ & $\begin{array}{l}\text { Controls susceptible to nematodes (low AA and low ZGB) vs BPX-413 } \\
\text { genotype }=\text { effect of high AA content and high ZGB content, } \\
\text { simultaneously, compared with controls with low AA + low ZGB }\end{array}$ \\
\hline C9 & $(\mathrm{T} 4+\mathrm{T} 5) / 2-(\mathrm{T} 8+\mathrm{T} 9+\ldots .+\mathrm{T} 34) / 27$ & $\begin{array}{l}\text { Controls with high AA and low ZGB vs BPX-413 lines = effect of high AA } \\
\text { content and high ZGB content, simultaneously, compared with the controls } \\
\text { with high AA }\end{array}$ \\
\hline $\mathrm{C} 10$ & $(\mathrm{~T} 6+\mathrm{T} 7) / 2-(\mathrm{T} 8+\mathrm{T} 9+\ldots .+\mathrm{T} 34) / 27$ & $\begin{array}{l}\text { Control with high AA and high ZGB vs BPX-413 lines = effect of high AA } \\
\text { content+ high ZGB content, simultaneously, compared with the controls } \\
\text { with high ZGB }\end{array}$ \\
\hline
\end{tabular}

\section{RESULTS AND DISCUSSION}

The genotypes tested presented significant differences by the $\mathrm{F}$ test at $5 \%$ probability in relation to repellency to spider mite in the measured times (20, 40 and 60 minutes) (Table 3). Homozygous genotypes with high AA content (TOM-687 and TOM-688), and homozygous genotypes with high ZGB content (ZGB-703 and ZGB-70) (Table 1) presented relatively short distance travelled by mites on the leaflets (Table 3), at all evaluation times, when compared with controls with low ZGB and AA contents ('Santa Clara' and TOM 584). This indicates the efficiency of both allelochemicals acting alone in repellency to mite (Table 3 and Table 4, C6 and C7 contrasts). Controls susceptible to nematodes and with low allelochemicals content ('Santa Clara' and TOM584) did not differ in relation to the distance travelled by mites in the first 20 minutes; subsequently, after 40 and 60 minutes, Santa Clara genotype presented travelled distances slightly greater than that of TOM-584 (Table 3 and Table 4, contrast $\mathrm{C} 1$ ).

Table 3. Mean distance travelled by mites on the leaflets surface, UFLA, Lavras, MG, 2014.

\begin{tabular}{|c|c|c|c|c|}
\hline \multirow[t]{2}{*}{ Id. } & \multirow[t]{2}{*}{ Treatments } & \multicolumn{3}{|c|}{ Distance traveled by the mite on the leaflet surface (mm) } \\
\hline & & 20 min* & 40 min* & 60 min* \\
\hline $\mathrm{T} 1$ & Santa Clara & $21,00 \mathrm{~g}$ & $29,60 \mathrm{j}$ & $35,600 \mathrm{k}$ \\
\hline $\mathrm{T} 2$ & TOM 584 & $20,00 \mathrm{~g}$ & $25,20 \mathrm{i}$ & $29,250 \mathrm{j}$ \\
\hline $\mathrm{T} 3$ & TOM 684 & $18,200 \mathrm{~g}$ & $24,75 \mathrm{i}$ & $27,750 \mathrm{j}$ \\
\hline $\mathrm{T} 4$ & TOM 687 & $9,75 \mathrm{f}$ & $14,20 \mathrm{~h}$ & $18,900 \mathrm{i}$ \\
\hline T5 & TOM 688 & $8,40 \mathrm{def}$ & $14,15 \mathrm{~h}$ & $18,950 \mathrm{i}$ \\
\hline T6 & ZGB 703 & $9,05 \mathrm{ef}$ & 13,25 fgh & $18,550 \mathrm{i}$ \\
\hline $\mathrm{T} 7$ & ZGB 704 & $8,25 \mathrm{def}$ & $12,90 \mathrm{efgh}$ & $18,400 \mathrm{hi}$ \\
\hline $\mathrm{T} 8$ & BPX-413E-02-161-207-31-6-20-325-107 & $8,60 \mathrm{def}$ & 11,75 defgh & 15,00defghi \\
\hline T9 & BPX-413E-02-161-207-31-6-20-325-116 & $6,70 \mathrm{bcdef}$ & $12,70 \mathrm{efgh}$ & 15,400efghi \\
\hline $\mathrm{T} 10$ & BPX-413E-02-161-207-31-6-20-325-125 & $4,65 \mathrm{abcd}$ & $8,55 \mathrm{abcdef}$ & $13,00 \mathrm{bcdefg}$ \\
\hline T11 & BPX-413E-02-161-207-31-6-20-325-128 & $6,60 \mathrm{bcdef}$ & $11,65 \mathrm{cdefgh}$ & 14,60defghi \\
\hline $\mathrm{T} 12$ & BPX-413E-02-161-207-31-6-20-325-129 & $7,85 \mathrm{cdef}$ & $14,35 \mathrm{~h}$ & 13,30 bcdefgh \\
\hline T13 & BPX-413E-02-161-207-31-6-6-367-102 & 4,80abcd & $10,75 \mathrm{bcdefgh}$ & 10,80abcde \\
\hline T14 & BPX-413E-02-161-207-31-6-6-367-107 & $8,00 \mathrm{def}$ & $13,75 \mathrm{gh}$ & $12,95 \mathrm{bcdefg}$ \\
\hline $\mathrm{T} 15$ & BPX-413E-02-161-207-31-6-6-367-111 & $1,90 \mathrm{a}$ & $4,40 \mathrm{a}$ & $6,90 \mathrm{a}$ \\
\hline $\mathrm{T} 16$ & BPX-413E-02-161-207-31-6-6-367-112 & $5,25 \mathrm{bcdef}$ & $6,90 \mathrm{abcde}$ & $8,40 \mathrm{ab}$ \\
\hline $\mathrm{T} 17$ & BPX-413E-02-161-207-31-6-6-367-113 & $7,15 \mathrm{cdef}$ & $13,50 \mathrm{gh}$ & 13,25 bcdefgh \\
\hline T18 & BPX-413E-02-161-207-31-6-6-367-114 & $6,85 \mathrm{cdef}$ & $10,95 \mathrm{cdefgh}$ & $11,85 \mathrm{bcdef}$ \\
\hline T19 & BPX-413E-02-161-207-31-6-6-367-115 & $6,05 \mathrm{bcdef}$ & 10,60bcdefgh & $13,35 \mathrm{bcdefgh}$ \\
\hline $\mathrm{T} 20$ & BPX-413E-02-161-207-31-6-6-367-126 & $8,15 \mathrm{def}$ & $10,60 \mathrm{bcdefgh}$ & $11,20 \mathrm{bcdef}$ \\
\hline $\mathrm{T} 22$ & BPX-413E-02-161-207-31-6-6-367-128 & $2,75 \mathrm{ab}$ & $5,75 \mathrm{ab}$ & $8,00 \mathrm{ab}$ \\
\hline $\mathrm{T} 23$ & BPX-413E-02-161-207-31-6-6-367-129 & $8,50 \mathrm{def}$ & 12,00defgh & 16,25 fghi \\
\hline $\mathrm{T} 24$ & BPX-413E-02-161-207-31-6-6-367-132 & $8,35 \mathrm{def}$ & $13,40 \mathrm{fgh}$ & 14,45 cdefghi \\
\hline $\mathrm{T} 25$ & BPX-413E-02-161-207-31-6-6-367-133 & $7,45 \mathrm{cdef}$ & $10,35 \mathrm{bcdefgh}$ & 14,35cdefghi \\
\hline $\mathrm{T} 26$ & BPX-413E-02-161-207-31-6-6-367-134 & $7,20 \mathrm{cdef}$ & $12,55 \mathrm{efgh}$ & $12,95 \mathrm{bcdefg}$ \\
\hline $\mathrm{T} 27$ & BPX-413E-02-161-207-31-6-6-367-135 & $7,60 \mathrm{cdef}$ & $12,25 \mathrm{efgh}$ & $12,50 \mathrm{bcdefg}$ \\
\hline
\end{tabular}




$\begin{array}{lllll}\text { T28 } & \text { BPX-413E-02-161-207-31-6-6-367-137 } & 6,85 \mathrm{cdef} & 11,65 \mathrm{cdefgh} & 12,85 \mathrm{bcdefg} \\ \text { T29 } & \text { BPX-413E-02-161-207-31-6-20-325-104 } & 8,00 \mathrm{def} & 14,95 \mathrm{~h} & 16,60 f \mathrm{ghi} \\ \text { T30 } & \text { BPX-413E-02-161-207-31-6-20-325-110 } & 7,50 \mathrm{cdef} & 12,50 \mathrm{efgh} & 15,00 \mathrm{defghi} \\ \text { T31 } & \text { BPX-413E-02-161-207-31-6-20-325-123 } & 5,00 \mathrm{bcdef} & 7,90 \mathrm{abcde} & 9,850 \mathrm{abcd} \\ \text { T32 } & \text { BPX-413E-02-161-207-31-6-20-325-124 } & 3,70 \mathrm{abc} & 8,15 \mathrm{abcdef} & 9,15 \mathrm{abc} \\ \text { T33 } & \text { BPX-413E-02-161-207-31-6-6-367-101 } & 7,75 \mathrm{cdef} & 12,70 \mathrm{efgh} & 17,65 \mathrm{ghi} \\ \text { T34 } & \text { BPX-413E-02-161-207-31-6-6-367-104 } & 6,30 \mathrm{bcdef} & 6,55 \mathrm{abc} & 8,25 \mathrm{ab}\end{array}$

* Significant by the $\mathrm{F}$ test at $5 \%$ significance level. Means followed by the same letter in the column do not differ by the Duncam test $(\mathrm{P}<0,05 \%)$.

The presence of the gene $M i$ in TOM-684 line did not decrease or annulled the distance travelled by the mite, since its effects were similar to those presented by the susceptible line TOM-584 in the measured times. The fact that TOM-584 and TOM-684 genotypes have the same behavior indicates that the gene $M i$ is not effective in conferring repellency to spider mite (Table 3 ). And, similarly to TOM-584, TOM-684 also did not differ from 'Santa Clara' until 20 minutes of evaluation (Table 3 and Table 4, C2 and C3 contrasts).

The repellency conferred by the genotypes rich in AA or ZGB to spider mite of the Tetranychus urticae genus in all measured times surpassed all controls, including TOM 684 (Table 3). In a similar study, Marchese (2013) did not observe differences between the susceptible controls, whether or not they carried the gene $M i$. On the other hand, Godzina et al. (2011) reported slow development of mites in relation to their development in tomato plants in the presence of the gene $M i$. Under field conditions, the resistance conferred by the gene $M i$ was incomplete dominance type, and the heterozygote presented intermediate resistance level.

The introduction of the gene $M i$ in tomato lines can be considered as a great advantage in providing to the plant a new resistance mechanism against the attack of nematodes of the Meloidogyne genus. Associated with high AA or ZGB contents, gene $M i$ could enhance the spectrum of resistance to other pests.

Homozygous genotypes rich in AA (TOM687 and TOM-688) presented no significant differences between each other, and numerically, they were very similar at all evaluation times (Table 3 and Table 4, contrast C4). Genotypes rich in ZGB (ZGB 703 and ZGB 704) also did not differ during evaluations (Table 3 and Table 4, contrast C5). There were no differences between the genotypes rich in AA and the genotypes rich in ZGB (Table 3), indicating similar effect of the allelochemicals in preventing or decreasing the distance traveled by the mite in the leaflet, and these results were also found by other authors (OLIVEIRA et al., 2012; NEIVA et al.,

2013).

Table 4. Contrasts of interest used to compare genotype and/or groups of genotypes with different zingiberene content (ZGB) and acylsugar content (AA). UFLA: Lavras, 2014.

\begin{tabular}{|c|c|c|c|c|}
\hline \multirow[t]{2}{*}{ Id. } & \multirow[t]{2}{*}{ Contrast of interest } & \multicolumn{3}{|c|}{ Estimates } \\
\hline & & $20 \mathrm{~min}$ & $40 \mathrm{~min}$ & $60 \mathrm{~min}$ \\
\hline $\mathrm{C} 1$ & T1-T2 & $1,00^{\mathrm{ns}}$ & $4,40^{*}$ & $6,35^{*}$ \\
\hline $\mathrm{C} 2$ & T1-T3 & $2,80^{\mathrm{ns}}$ & $4,85^{*}$ & $7,85^{*}$ \\
\hline $\mathrm{C} 3$ & T2-T3 & $1,80^{\mathrm{ns}}$ & $0,45^{\mathrm{ns}}$ & $1,50^{\mathrm{ns}}$ \\
\hline $\mathrm{C} 4$ & T4-T5 & $1,35^{\mathrm{ns}}$ & $0,05^{\mathrm{ns}}$ & $-0,05^{\mathrm{ns}}$ \\
\hline $\mathrm{C} 5$ & T6-T7 & $0,80^{\mathrm{ns}}$ & $0,35^{\mathrm{ns}}$ & $0,15^{\mathrm{ns}}$ \\
\hline C6 & $(\mathrm{T} 1+\mathrm{T} 2) / 2-(\mathrm{T} 4+\mathrm{T} 5) / 2$ & $11,42^{*}$ & $13,22^{*}$ & $13,50^{*}$ \\
\hline $\mathrm{C} 7$ & $(\mathrm{~T} 1+\mathrm{T} 2) / 2-(\mathrm{T} 6+\mathrm{T} 7) / 2$ & $11,85^{*}$ & $14,32^{*}$ & $13,95^{*}$ \\
\hline $\mathrm{C} 8$ & $(\mathrm{~T} 1+\mathrm{T} 2) / 2-(\mathrm{T} 8+\mathrm{T} 9+\mathrm{T} 10+. .+\mathrm{T} 34) / 27$ & $13,98^{*}$ & $16,58^{*}$ & $19,81^{*}$ \\
\hline $\mathrm{C} 8$ & $(\mathrm{~T} 4+\mathrm{T} 5) / 2-(\mathrm{T} 8+\mathrm{T} 9+\mathrm{T} 10+. .+\mathrm{T} 34) / 27$ & $2,55^{*}$ & $3,36^{*}$ & $6,31^{*}$ \\
\hline $\mathrm{C} 10$ & $(\mathrm{~T} 6+\mathrm{T} 7) / 2-(\mathrm{T} 8+\mathrm{T} 9+\mathrm{T} 10+. .+\mathrm{T} 34) / 27$ & $2,13^{*}$ & $2,26^{*}$ & $5,86^{*}$ \\
\hline
\end{tabular}

${ }^{\mathrm{ns}}$ and $*$ not significant and significant by the $\mathrm{t}$ test at $5 \%$ probability, respectively.

The distance travelled by the mites in BPX413E clones selected for high acylsugar and zingiberene contents was shorter in relation to controls with low allelochemicals content ('Santa Clara' and TOM 584) in all the measured times (Table 4, C8). This result was expected when compared with clones and with TOM-684 line (carrying the gene $\mathrm{Mi}$ ), since this line (TOM-684) has the same resistance level as TOM-584, as discussed above. Thus, the gene Mi present in TOM 684 is not effective in repelling mite; however, it is 
another tool to be used in breeding programs aiming at pest resistance.

In general, all the BPX-413E clones selected presented, in the evaluation times (20, 40 and 60 minutes), distances covered by the mite equal or smaller than treatments rich in AA alone or ZGB, especially with regard to mean distances covered by the mites after 40 minutes (Table 4, C8, C9 and C10). Similar results were found by Silva et al. (2009) and Maluf et al. (2001), which proves that resistance of $T$. urticae mites mediated by the alelochemical was higher in 40 and 60 minutes.

The highest repellency level presented by the clones indicates the existence of synergistic effect of allelochemicals for resistance to spider mite, and demonstrates the advantage of investing in simultaneous selection for both allelochemicals. In similar works carried out by Silva (2009) and Maluf et. al (2001), synergistic effect for mite was not detected, perhaps, for they have tested double heterozygote genotype both for AA and for ZGB, contrary to what was demonstrated by Silva et al. (2009) in tests for resistance to Tuta absoluta. Several studies have confirmed the efficiency of allelochemicals in resistance and/or repellency to spider mite (RESENDE et al., 2002, GONÇALVES et al., 2006, SILVA et al., 2009, MALUF et al., 2010). However, none of them have found the effect of homozygous treatments rich in both allelochemicals. The only work in this sense was carried out by Silva et al. (2009); nevertheless, the synergistic effects were evaluated in heterozygote hybrids for both AA and ZGB. The effects on nonsegregating lines for both $\mathrm{AA}$ and ZGB were not evaluated.

\section{CONCLUSIONS}

The gene $M i$ was not effective in conferring repellency to spider mite, although it may be advantageous for tomato breeding programs aiming at resistance to other pests.

Zingiberene (ZGB) or acylsugar (AA) were efficient and equivalent in promoting repellency to mite of the Tetranychus urticae genus.

Zingiberene and acylsugar combined in tomato lines presented synergistic effect, which increased repellency to mite.

\section{ACKNOWLEDGMENTS}

To the Research Support Foundation of the State of Minas Gerais (FAPEMIG); to $\mathrm{CNPq} /$ National Council for Scientific and Technological Development (MCT); to the Coordination for the Improvement of Higher Education Personnel (Capes/ MEC); to the Federal University of Lavras (UFLA), to the Organic Chemistry Laboratory Essential oils (DQI/UFLA); and to Empresa Hortiagro Sementes S.A.

RESUMO: O tomate (Solanum Lycopersicum) é um produto destinado à alimentação humana, seja na forma industrializada ou "in natura". A expansão da área de cultivo dessa cultura favoreceu, entretanto, o surgimento de pragas e de doenças de difícil controle, que afetam significantemente a sua produção. Assim, o objetivo, neste trabalho, foi quantificar e comparar os efeitos do gene Mi, do alto teor de AA (isoladamente), do alto teor de ZGB (isoladamente) e dos altos teores de AA e ZGB (simultaneamente) na repelência de linhagens de tomateiro ao ácaro-rajado Tetranychus urticae, e detectar possíveis efeitos sinergísticos da presença dos dois aleloquímicos relativamente à presença de só um deles, isoladamente. O delineamento utilizado foi inteiramente casualizado, com 4 repetições. Foram retirados 4 folíolos expandidos de tamanhos semelhantes no terço superior das plantas em estádio fenológico de pré-florescimento. O bioensaio foi realizado no interior de câmara fria, à temperatura de $16 \pm 1^{\circ} \mathrm{C}$ e umidade relativa de $64 \pm 4 \%$. A resistência conferida pelos genótipos ricos em AA ou ZGB, na repelência ao ácaro-rajado do gênero Tetranychus urticae, em todos os tempos avaliados, superou todas as testemunhas, inclusive o TOM 684. O gene Mi não alterou na resistência. Houve efeito sinergístico entre AA e ZGB.

PALAVRAS-CHAVE: Tetranychus urticae, Solanum lycopersicum. Melhoramento genético

\section{REFERENCES}

BLEEKERA, P. M.; MIRABELLAA, R.; DIERGAARDEB, P. J.; VANDOORNB, A.; TISSIERC, A.; KANTD, M. R.; PRINSB, M.; VOSB, M.; HARINGA, M. A.; SCHUURINK, R. C. (2012). Improved herbivore resistance in cultivated tomato with the sesquiterpene biosynthetic pathway from a wild relative.

PNAS, v.109, p. 20124-20129, 2012. 
EMBRAPA HORTALIÇAS-CNPH. Sistemas de Produção. 2009. Brasília: Embrapa hortaliças, 2009. P. Disponível em: http://sistemasdeproducao.cnptia.embrapa.br/FontesHTML/Tomate. Acesso em: 13 fev. 2011.

FADINI, M. A. M.; VENZON, M.; OLIVEIRA, H. G.; PALLINI, A. 2006. Manejo integrado das principais pragas do morangueiro. Boletim do morango: cultivo convencional, segurança alimentar, cultivo orgânico Belo Horizonte: FAEMG, 2006. p. 81-95.

FAO. Faostat: Premilinary 2011 data now available. Disponivel em, http://faostat.fao.org/site/567/DesktopDefault.aspx?PageID=567\#ancor Acesso em 28 de janeiro de 2013.

FLECHTMANN, C. H. W., BAKER, E. W. (1970). A preliminary report on the Tetranychidae (Acarina) of Brazil. Annals of the Entomological Society of America, v. 63, p. 156-163, 1970.

FREITAS, J. A. Resistência genética de tomateiro Lycopersicon spp. à mosca-branca Bemisia spp.mediada por zingibereno contido em tricomas glandulares. 1999. 93 p. Tese (Doutorado em Genética e Melhoramento de Plantas) - Universidade Federal de Lavras, Lavras, MG.

GODZINA, M.; KIELKIEWICZ, M.; SZYMCZYKIEWICZ, K. (2011). Varying abundance and dispersal of the two-spotted spider mite (Tetranychus urticae Koch, 1836, Acari: prostigmata: Tetranychidae) on Mi-tomato plants differing in allelic combination. Biological Lett, v. 48, p. 213-223, 2011.

GONÇALVES NETO A. C.; SILVA, V. F.; MALUF, W. R.; MACIEL, G. M.; NIZIO, D. A. C.; GOMES, L. A. A.; AZEVEDO, S. M. 2010. Resistência à traça-do-tomateiro em plantas com altos teores de acilaçúcares nas folhas. Horticultura Brasileira, v. 28, p. 203-208, 2010.

GONÇALVES, L. D.; MALUF, W. R.; CARDOSO, M. G.; RESENDE, J. T. V.; CASTRO, E. M.; SANTOS, N. M.; NASCIMENTO, I. R.; FARIA, M. V. 2006. Relação entre zingibereno, tricomas foliares e repelência de tomateiros a Tetranychus evansi. Pesquisa agropecuária brasileira, v. 41, p. 267-273, 2006.

KALOSHIAN, I., KINSEY, M. G.; WILLIAMSON, V. M.; ULLMAN, D. E. 2000. Mi-mediated resistance against the potato aphid Macrosiphum euphorbiae (Hemiptera: Aphididae) limits sieve element ingestion. Environmental Entomology, v.2 9, p. 690-695, 2000.

LARA, F. M. (1991). Princípios de resistência de plantas aos insetos. 2. ed. São Paulo: Ícone, P.336.

MACIEL, G. M; MALUF, W. R; SILVA, V. F; GONÇALVES NETO, A. C; GOMES, L. A. A. (2011).

Híbridos pré-comerciais resistentes a Tuta absoluta obtidos de linhagem de tomateiro rica em acilaçúcares.

Horticultura Brasileira, v. 29, p. 151-156, 2011.

MALUF, W. R.; CAMPOS, G. A.; CARDOSO, M. G.(2001). Relationships between trichome types and spider mite (Tetranychus evansi) repellence in tomatoes with respect to foliar zingiberene contents. Euphytica, v. 121, p. 73-80, 2001.

MALUF, W. R.; MACIEL, G. M.; GOMES, L. A. A.; CARDOSO, M. G.; GONÇALVES, L. D.; SILVA, E. C.; KNAPP, M. (2010). Broad-Spectrum Arthropod Resistance in Hybrids between High- and Low-Acylsugar Tomato Lines. Crop Science, v. 50, p. 439-450, 2010.

MALUF, W. R.; SILVA, V. F.; GOMES, L. A. A.; GONÇALVES NETO, A. C.; MACIEL, G. M.; NÍSIO, D. A. C. (2010). Resistance to the South American tomato pinworm Tuta absoluta in high acylsugar and/or high zingiberene tomato genotypes. Euphytica, v. 176, p. 113-123, 2010.

MARCHESE, A. Resistência à Mosca- Branca e ao Ácaro-Rajado Mediada por Acilaçúcares e pelo Gene Mi em Tomateiro. 2013. 63 p. Tese (Doutorado em Agronomia/Fitotecnia) - Universidade Federal de Lavras,

Lavras, MG. 
NEIVA, I. P, ANDRADE JÚNIOR, V. C, MALUF, W. R.; OLIVEIRA, C. M.; MACIEL, G. M. (2013). Role of allelochemicals and trichome density in the resistance of tomato to whitefly. Ciência e agrotecnologia, $v$. 37, p. 61-67, 2013.

OLIVEIRA, C. M.; ANDRADE JÚNIOR, V. C.; MALUF, W.R.; NEIVA, I. P.; MACIEL, G. M. (2012). Resistance of tomato trains to the moth Tuta absoluta imparted by allelochemicals and trichome density. Ciência e agrotecnologia, v. 36, p. 45-52, 2012.

PAULA JÚNIOR, T. J; VENZON, M. (2007). 101 culturas: Manual de tecnologias agrícolas. Belo Horizonte: EPAMIG. P. 800..

PEREIRA, G. V. N; MALUF, W. R.; GONÇALVES, L. D.; NASCIMENTO, I. R.; GOMES, L. A. A; LICURSI, V. (2008). Seleção para alto teor de acilaçúcares em genótipos de tomateiro e sua relação com a resistência ao ácaro vermelho (Tetranychus evansi) e à traça (Tuta absoluta). Ciência e Agrotecnologia, v. 32, p. 996-1004, 2008.

RESENDE, J. T. V.; MALUF, W. R.; CARDOSO, M. G.; NELSON, D. L.; FARIA, M. V. (2002). Inheritance of acylsugar contents in tomatoes derived from an interspecific cross with the wild tomato Lycopersicon pennellii and their effect on spider mite repellence. Genetics and Molecular Research, v. 1, p. 106-116, 2002.

RESENDE, J. T. V.; MALUF, W. R.; FARIA, M. V.; PFANN, A. Z.; NASCIMENTO, I. R. (2006). Acylsugars in tomato leaflets confer resistance to the South American tomato pinworm, Tuta absoluta Meyr. Scientia Agricola, v. 63, p. 20-25, 2006.

RESENDE, J. T. V.; MALUF, W. R.; CARDOSO, M. V.; GONSALVES, L. D.; NASCIMENTO, I. R. (2008). Resistence of tomato genotypes with high level of acylsugars to Tetranychus evansi Baker \& pritchard.

Scientia Agricola, v. 65, p. 31-35, 2008.

ROBERTS, P. A.; THOMASON, I. J. (1986). Variability in reproduction of isolates of Meloidogyne incognita and M. javanica on resistant tomato genotypes. Plant Disease, 69, 896-898.

Cary, N.C. (1990). SAS Institute. SAS/STAT User.s Guide. SAS Institute.

SILVA, A. A; MALUF, W. R; MORAES, J. C; ALVARENGA, R; RODRIGUES COSTA, E. M. (2013) Resistência a Myzus persicae em genótipos de tomateiro com altos teores foliares de aleloquímicos. Bragantia, Campinas, v. 72, p. 173-179, 2013.

SILVA, V. F.; MALUF, W. R.; CARDOSO, M. G.; GONÇALVES NETO, A. C.; MACIEL, G. M.; NÍZIO, D. A. C.; SILVA, V. A. (2009). Resistência mediada por aleloquímicos de genótipos de tomateiro à mosca-branca e ao ácaro-rajado. Pesquisa agropecuária. brasileira, v. 44,p. 1262-1269, 2009.

SILVA, V. F.; MALUF, W. R.; CARDOSO, M. G.; NETO, A. C. G.; MACIEL, G. M.; NÍZIO, D. A. C.; SILVA, V. A. (2009). Resistência mediada por aleloquímicos de genótipos de tomateiro à mosca-branca e ao ácaro-rajado. Pesquisa agropecuária brasileira, v. 44, p. 1262-1269, 2009.

SMITH, P. G. (1944). Embryo culture of a tomato species hybrid. Proceedings of the American Society of Horticultural Science, v. 44, p. 413-416, 1944. 